\title{
Immune Status and Chemokine C Receptor 7 Expression in Primary in Patients with Immune Thrombocytopenia
}

\author{
Primer İmmün Trombositopeni Hastalarında Immün Durum ve Kemokin C Reseptör \\ Ekspresyonu
}

(D) Lin Zhang\#, (D) Guo-zhong Zhou\#, (D) Wei-ying Feng, (D) Dan Li

Shaoxing People's Hospital, Department of Hematology, Zhejiang Province, China

\#These authors contributed equally to this work.

\section{Abstract}

Objective: The present study investigated immune disorders and chemokine $\mathrm{C}$ receptor 7 (CCR7) expression in primary immune thrombocytopenia (ITP) patients and analyzed their changes and clinical significance before and after treatments.

Materials and Methods: Flow cytometry was used to detect the proportion of different immune cell subsets in the peripheral blood of 42 patients with ITP and 20 healthy controls at different time points. Treatments included first-line drugs, such as glucocorticoids and intravenous immunoglobulin, and second-line therapy, such as interleukin-11 and thrombopoietin receptor agonists.

Results: An elevated CD4/CD8 ratio and decreased natural killer (NK) cells and $\mathrm{CD} 4{ }^{+} \mathrm{CD} 25^{+} \mathrm{CD} 127^{\text {low }}$ regulatory T-cells (Tregs) were found in pretreatment ITP patients compared to healthy controls. The newly diagnosed group had a higher CD4/CD8 ratio and more NK cells than the relapsed group. Treg levels of the remission group were higher than those of the recurrence group. The $\mathrm{CD}^{+}{ }^{+} \mathrm{CR} 7^{+}, \mathrm{CD}^{+}{ }^{+} \mathrm{CR} 7^{+}$, and $\mathrm{CCR}^{+}$subsets of $\mathrm{B}$ cells and NK cells showed higher increases in the newly diagnosed and relapsed group compared to controls and the remission group. The values for the $\mathrm{CD} 4{ }^{+} \mathrm{CCR} 7{ }^{+}$and $\mathrm{CD} 8{ }^{+} \mathrm{CCR} 7{ }^{+}$subsets in the relapsed group were slightly higher than those in the newly diagnosed group. The CCR7 ${ }^{+}$subsets of CD4 ${ }^{+}$T-cells, CD8 ${ }^{+}$T-cells, NK cells, and B cells had lower values in the remission group compared to the relapsed group. Higher levels of the $\mathrm{CD} 8^{+} \mathrm{CCR} 7^{+}$subset and lower levels of NK cells were found in the remission group compared to the controls. The ratio between the $\mathrm{CD} 4^{+} \mathrm{CCR} 7^{+}$subset and $\mathrm{CD} 8^{+} \mathrm{CCR} 7^{+}$ subset was lower in ITP patients than in healthy controls. There was a negative correlation between the $\mathrm{CD} 8{ }^{+} \mathrm{CCR} 7^{+}$subset and platelet count in the ITP patients.

Conclusion: ITP patients with CCR7 had immune disorders and high heterogeneity, and CCR7 was found to be involved in the pathogenesis of ITP. Further studies are needed to investigate effective treatments for ITP by targeted regulation of CCR7.

Keywords: Primary immune thrombocytopenia, Immune state, Chemokine $\mathrm{C}$ receptor 7 , T-cells

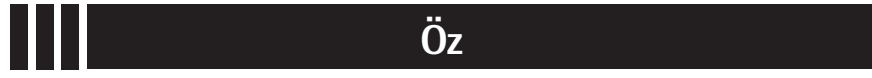

Amaç: Bu çalışmada, primer immün trombositopeni (ITP) hastalarında immün bozuklukları ve kemokin $C$ reseptörü 7 (CCR7) ekspresyonu araştırıldı ve tedavilerden önce ve sonra değişiklikleri ve klinik önemi analiz edildi.

Gereç ve Yöntemler: Akım sitometri kullanılarak 42 ITP hastasının ve 20 sağlıklı kontrolün farklı zamanlarda periferik kanındaki farklı immün hücre alt gruplarının oranı saptandı. Tedaviler, glukokortikoidler ve intravenöz immünoglobulin gibi birinci basamak ve interlökin-11 ve trombopoietin reseptör agonistleri gibi ikinci basamak ilaçları içeriyordu.

Bulgular: Sağlıklı kontrollerle karşılaştırıldığında tedavi öncesi ITP hastalarında CD4/CD8 oranı yüksek, ve doğal öldürücü (NK) hücreler ile $\mathrm{CD}^{+} \mathrm{CD} 25^{+} \mathrm{CD} 127^{\text {düşük }}$ düzenleyici T hücreleri (Treg) düşük olarak bulundu. Yeni tanı grubunda, nüks eden gruba göre CD4/CD8 oranı daha yüksek ve NK hücresi ise daha fazlaydı. Remisyon grubunun Treg seviyeleri, nüks grubundan daha yüksekti. B hücrelerinin ve $\mathrm{NK}$ hücrelerinin $\mathrm{CD}^{+} \mathrm{CCR}^{+}, \mathrm{CD} 8^{+} \mathrm{CCR} 7^{+}$ve $\mathrm{CCR} 7^{+}$alt kümeleri, yeni tanı ve nüks eden grupta kontrollere ve remisyon grubuna kıyasla daha fazla oranda artış gösterdi. Nüks eden gruptaki $\mathrm{CD} 4^{+} \mathrm{CCR} 7^{+}$ ve $\mathrm{CD}^{+} \mathrm{CCR}^{+}$alt grupları için değerler, yeni tanı konan gruptan biraz daha yüksekti. $\mathrm{CD} 4^{+} \mathrm{T}$ hücrelerinin, $\mathrm{CD} 8^{+} \mathrm{T}$ hücrelerinin, NK hücrelerinin ve $\mathrm{B}$ hücrelerinin $\mathrm{CCR7}^{+}$alt kümeleri, relaps grubuna kıyasla remisyon grubunda olanlarda daha düşüktü. Kontrollere kıyasla remisyon grubunda $\mathrm{CD} 8^{+} \mathrm{CCR} 7^{+}$alt grubunun değerleri daha yüksek ve NK hücrelerinin ise daha düşük bulundu. $C D 4^{+} C C R 7^{+}$hücrelerin $\mathrm{CD}^{+}{ }^{+} \mathrm{CR} 7^{+}$hücrelere oranı, ITP hastalarında sağlıklı kontrollere göre daha düşüktü. ITP hastalarında $\mathrm{CD}^{+} \mathrm{CCR} 7^{+}$alt grubu ile trombosit sayısı arasında negatif korelasyon vardı.

Sonuç: CCR7 ekspresyonu olan ITP hastalarında immün bozukluklar ve yüksek heterojenite vardı ve CCR7'nin ITP'nin patogenezinde rol oynadığı bulundu. CCR7'nin hedeflenen regülasyonu ile ITP'nin etkin tedavisini araştıracak daha fazla çalışmaya intiyaç vardır.

Anahtar Sözcükler: Birincil immün trombositopeni, İmmün durumu, Kemokin $C$ reseptörü 7, $\mathrm{T}$ hücreler

๑Copyright 2022 by Turkish Society of Hematology

Turkish Journal of Hematology, Published by Galenos Publishing House



Received/Geliş tarihi: May 2, 2021 Zhejiang Province, China

Phone : +86 575-88229342

E-mail : lidalidan1314@163.com ORCID: orcid.org/0000-0001-5086-610X 


\section{Introduction}

Primary immune thrombocytopenia (ITP) is an autoimmune disease characterized by increased platelet destruction and reduced platelet production. ITP has an increased bleeding risk depending on disease severity [1]. The complex pathogenesis of ITP has not yet been fully elucidated. The presence of autoreactive antibodies against platelet glycoproteins, such as GP IIb/IIla and GP Ib/IX, is considered to play a central role in the cause of ITP. However, dysfunctional cellular immunity has also recently been found to be important in the pathogenesis of ITP [2]. Treatments for ITP are difficult due to the diversity seen in the pathogenesis of ITP. Therefore, it is of vital importance to identify commonalities in the diversity of the pathogenesis of ITP for more precise treatment in the future.

It is well known that a variety of immune cells are involved in the destruction and generation of platelets in ITP. The immune system is involved in ITP pathogenesis together with the production of cytokine mediators and certain cellular subpopulations participate in many different immune phenomena [3]. Due to the heterogeneity of ITP, the results of various studies addressing these topics are contradictory.

Chemokines are a group of small (8-14 kDa) structurally related molecules that regulate the trafficking of various cells by binding to chemokine receptors, which are also structurally related and contain seven transmembrane domains coupled to a $\mathrm{G}$ protein [4]. Chemokine $\mathrm{C}$ receptor 7 (CCR7 or CD197) and its ligation with chemokines CCL19 and CCL21 participate in T-cell homeostasis and trafficking as well as amplifying antigen-specific T-cell responses and T-cell homeostatic proliferation, suggesting a relationship with autoimmunity [5]. Research has shown that
CCR7 signaling delivers costimulatory signals during early T-cell receptor activation, leading to enhanced IFN- $\gamma$ production and Th1 polarization. Thus, active CCR7 signaling favors Th1 polarization of T-cells [6]. It has also been reported that the expression of CCR7 on $\mathrm{CD}^{+} \mathrm{T}$-cells in peripheral blood inhibits the apoptosis of CD8 ${ }^{+}$-cells [7]. Whether the above effects are also present in ITP needs further exploration. Moreover, CCR7 plays an important role in autoimmune diseases mediated by T-cell subsets, such as experimental dry eye disease [8], multiple sclerosis (experimental autoimmune encephalomyelitis) [9], and arthritis [10]. Based on the functional importance of CCR7 in immune cells and autoimmune diseases, we measured the proportion of peripheral blood (PB) mononuclear cells and the expression of CCR7 in PB mononuclear cells within a cohort of ITP patients before and after treatment, and we analyzed differences in that relationship between different groups according to curative effect.

\section{Materials and Methods}

\section{Study Participants}

Approval of the Institutional Review Board was obtained from Shaoxing People's Hospital for the present study, and informed consent was obtained from patients and healthy donors to allow their information to be used in this study in accordance with the Declaration of Helsinki.

All patients met the diagnostic criteria reported by the 2010 International Consensus of Primary Immune Thrombocytopenia, including "newly diagnosed ITP" referring to a disease present for fewer than 3 months. Forty-two patients newly diagnosed with primary ITP were enrolled in this study (Table 1), and 20 healthy volunteers were examined as the control group.

\begin{tabular}{|c|c|c|c|c|}
\hline Cell types & Controls & New patients & Relapsed & Remission \\
\hline Platelet count (mean \pm SD) & $214.90 \pm 30.02$ & $12.21 \pm 8.60$ & $20.46 \pm 16.91$ & $158.15 \pm 34.96$ \\
\hline $\mathrm{CD}^{+}$T-cells (mean $\left.\pm \mathrm{SD}\right)$ & $77.39 \pm 5.39$ & $74.06 \pm 6.37$ & $78.30 \pm 6.86$ & $76.89 \pm 4.22$ \\
\hline CD4+ T-cells (mean \pm SD) & $40.01 \pm 4.42$ & $45.79 \pm 8.51^{*}$ & $46.02 \pm 10.35$ & $41.58 \pm 4.43$ \\
\hline CD8+ T-cells (mean \pm SD) & $32.46 \pm 3.26$ & $31.43 \pm 5.56^{*}$ & $47.39 \pm 8.38^{* \#}$ & $32.53 \pm 2.74^{*}$ \\
\hline $\mathrm{CD}^{+} / \mathrm{CD}^{+}+\mathrm{T}$-cells (mean $\pm \mathrm{SD}$ ) & $1.29 \pm 0.12$ & $1.48 \pm 0.26^{*} \$$ & $1.00 \pm 0.32$ & $1.29 \pm 0.18$ \\
\hline$B$ cells (mean $\pm S D)$ & $4.50 \pm 1.29$ & $3.62 \pm 1.25$ & $4.87 \pm 1.81$ & $4.58 \pm 0.97$ \\
\hline NK cells (mean $\pm S$ D) & $15.33 \pm 4.32$ & $10.97 \pm 3.95^{* \$}$ & $15.20 \pm 3.84$ & $12.92 \pm 3.85$ \\
\hline Tregs (mean \pm SD) & $5.42 \pm 1.13$ & $4.11 \pm 0.99^{*}$ & $4.14 \pm 0.98^{*}$ & $5.63 \pm 1.02^{\$ \# \#}$ \\
\hline CD4+CD197+ T-cells (mean \pm SD) & $26.64 \pm 5.66$ & $48.33 \pm 6.45^{*}$ & $54.87 \pm 6.96^{* \# \#}$ & $28.16 \pm 5.75^{\$ \# \#}$ \\
\hline CD8+CD197+ T-cells (mean \pm SD) & $4.03 \pm 1.15$ & $16.51 \pm 2.46^{*}$ & $20.92 \pm 2.40^{*}$ & $9.75 \pm 3.15^{* \# \# \#}$ \\
\hline CD19+CD197+ $B$ cells (mean \pm SD) & $4.60 \pm 1.41$ & $16.70 \pm 2.58^{*}$ & $18.71 \pm 2.20^{*}$ & $7.09 \pm 3.38^{\text {\$\#\# }}$ \\
\hline $\mathrm{CD}_{197^{+}} \mathrm{NK}$ cells (mean \pm SD) & $22.20 \pm 3.44$ & $34.87 \pm 7.96^{*}$ & $36.07 \pm 4.28^{*}$ & $17.27 \pm 4.12^{* \$ \# \#}$ \\
\hline \multicolumn{5}{|c|}{$\begin{array}{l}\text { NK: Natural killer; Tregs: regulatory T-cells; SD: standard deviation. } \\
p<0.05 \text { compared to healthy controls. } \\
{ }^{\$ p} p<0.05 \text { compared to relapsed group. } \\
{ }^{\# "} p<0.05 \text { compared to newly diagnosed patients. } \\
" p<0.05 \text { compared to newly diagnosed patients and remission group. }\end{array}$} \\
\hline
\end{tabular}


According to careful follow-up of the 42 newly diagnosed ITP patients, 13 patients were in relapse and 13 patients were in complete remission (CR); others were lost to follow-up. The newly diagnosed group, which had not received any initial treatment, consisted of 23 men and 19 women with a mean age of $46.50 \pm 21.40$ years. Thirteen patients, consisting of 6 men and 7 women with a mean age of $45.23 \pm 20.23$ years, were treated and evaluated for CR. The relapsed group $(n=13)$ consisted of 7 men and 6 women with a mean age of $50.20 \pm 14.60$ years who lost $\mathrm{CR}$ or response (platelet count below $50 \times 10^{9} / \mathrm{L}$, bleeding after $C R$, or less than a twofold increase in baseline platelet count from CR where "baseline platelet count" refers to the platelet count at the time of starting the initial treatment). The control group included 11 men and 9 women with a mean age of $40.20 \pm 18.60$ years whose physical examinations proved that they were healthy. Blood samples from the patients and the control group were processed and tested in the same assays.

\section{Treatment}

The patients in this retrospective study were all treated with intravenous immune globulin (400 $\mathrm{mg} / \mathrm{kg}$ per day for 3-5 days) plus corticosteroids (dexamethasone at $40 \mathrm{mg}$ per day for 4 days or prednisone at $1.0 \mathrm{mg} / \mathrm{kg}$ per day for 1-3 weeks and then tapered) according to first-line treatment standardization. Some patients with severe bleeding symptoms were also given platelet transfusions to increase platelet counts. In addition to standard therapy, cyclosporine A, rituximab, vincristine, azathioprine, danazol, interleukin-11, and thrombopoietin were used as salvage therapies for nonresponsive patients.

\section{Treatment Responses}

Treatment responses were evaluated according to the consensus definition of the International Working Group [4], including CR (complete remission) and R (relapse). In our study, the criteria to assess these responses were as follows: $C R$, platelet count of $\geq 100 \times 10^{9} / \mathrm{L}$ and the absence of bleeding; $R$, platelet count of $<30 \times 10^{9} / \mathrm{L}$, bleeding, or less than a twofold increase in baseline platelet count or bleeding after CR. Blood samples were collected from the patients before they started treatment with thrombopoietic agents in the "newly diagnosed" and "relapsed" groups. After treatment, blood samples were collected from patients at the time of maximal response. The study observation period to assess the response was at least 6 months at the time of the last visit or until death (due to any cause) if death occurred before that date.

\section{Flow Cytometry}

The monoclonal antibodies (mAbs) specific for human surface antigens were purchased from BD Biosciences (San Jose, CA, USA). Peripheral blood mononuclear cells (PBMCs; 2-5 mL) were isolated from whole blood by Ficoll-Hypaque (Amersham Biosciences, Uppsala, Sweden) gradient centrifugation.
Mononuclear cells were washed in AIM-V medium (Life Technologies, Grand Island, NY, USA), counted in the presence of trypan blue dye, and immediately used for experiments.

\section{Detection of T-Cell Subsets, B Cells, NK Cells, and Regulatory T-Cells}

The T-cell subsets $\left(\mathrm{CD} 3^{+}{ }^{+}\right.$-cells, $\mathrm{CD} 3^{+} \mathrm{CD} 4^{+}$helper T-cells, and $\mathrm{CD}^{+}{ }^{+} \mathrm{CD} 8^{+}$cytotoxic T-cells), CD19+ $\mathrm{B}$ cells, and CD16 ${ }^{+} \mathrm{CD} 56^{+}$ NK cells in $\mathrm{PB}$ were stained with two- and three-color mAbs using PercpCy5.5-conjugated anti-CD3 mAbs, CD16-specific mAbs, PE-conjugated CD8-specific mAbs, FITC-conjugated CD4-specific mAbs, CD19-specific mAbs, CD56-specific mAbs, and APC-conjugated CD45-specific mAbs. The isolated PBMCs $\left(1 \times 10^{6}\right)$ were stained with the above antibodies for $15 \mathrm{~min}$ at $4{ }^{\circ} \mathrm{C}$ in the dark according to the manufacturer's protocol and then the PBMCs (300-500 $\mu \mathrm{L})$ were analyzed by multiparameter flow cytometry within $1 \mathrm{~h}$.

Samples were anticoagulated with heparin and examined within $4 \mathrm{~h}$. Approximately $100 \mu \mathrm{L}$ of PB mononuclear cells $\left(6 \times 10^{5}\right)$ from $P B$ was incubated in the dark for $20 \mathrm{~min}$ with FITC-conjugated CD25-specific mAbs, PE-conjugated CD127-specific mAbs, and PercpCy5.5-conjugated anti-CD4 mAbs. Antihuman immunoglobulin $\mathrm{G}$ was used as an isotypematched negative control for all samples. After incubation, red blood cell lysis, and washing with phosphate-buffered saline, a fixation solution was added for $10 \mathrm{~min}$. Cells were then assessed by flow cytometry and analyzed using FlowJo 7.6.1 software. Within the CD4+ T-cell gate on lymphocytes, CD4+ regulatory T-cells (Tregs) were identified as $C D 25^{+} \mathrm{CD} 127^{\text {low. }}$.

\section{Statistical Analysis}

The $R$ language (version 4.0.4) was used for data analysis and visualization. The dplyr and ggstatsplot packages were used for data and statistical processing while ggplot2 packages were used for data visualization. The differences in the percentages of cell types between control subjects and ITP patients were analyzed by Games-Howell test. The Pearson correlation coefficient was used to evaluate the correlation between variables in different groups. Values of $p<0.05$ were considered statistically significant.

\section{Results}

\section{Immune Status in ITP}

All patients involved in this study had newly diagnosed ITP, and they were all subjected to autoimmune screening and had no history of lymphoproliferation or severe/recurrent/atypical infections. Based on the follow-up of these newly diagnosed ITP patients, they were divided into the following two groups: relapse and complete remission. Hemorrhagic symptoms were present in 10 patients $(23.8 \%)$ in the form of petechial hemorrhage and some bruising. None of the patients had 
enlarged liver, enlarged spleen, or lymphadenopathy. There were no significant differences in age or sex between the ITP and control groups. Platelet count was significantly decreased in the ITP patients compared to the controls. No significant differences were detected in the proportions of $\mathrm{CD}^{+} \mathrm{T}$ and $\mathrm{B}$ lymphocytes between the ITP patients and controls. The overall $p$-value was 0.012 , showing a statistical difference, but there was no statistical difference between the ITP patients and controls in terms of B lymphocytes ( $>0.05)$. Perhaps our small sample size led to a reduction in the statistical effect. In addition, the number of groups that we compared was relatively large, which may also lead to lower statistical effect and overall differences after correction (Figures $1 \mathrm{~A}$ and $2 \mathrm{~A}$ ). CD4 ${ }^{+} \mathrm{T}$-cells were increased in the newly diagnosed patients compared to the controls $(p=0.027$, Figure $1 B)$, and $C D 8^{+}$T-cells showed the highest increase in relapsed patients compared to the other groups

\section{A}



C

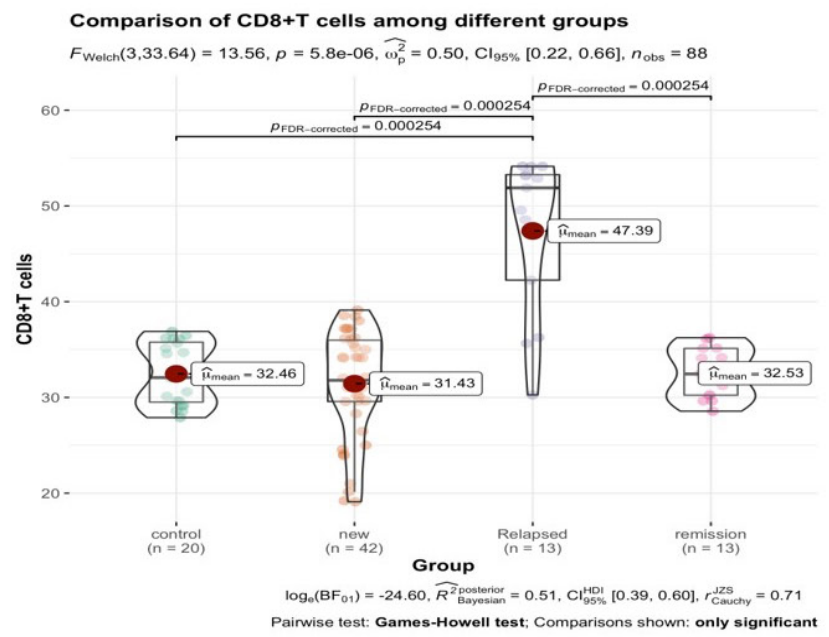

( $p<0.0001$, Figure $1 \mathrm{C})$. An elevated CD4/CD8 ratio, a decreased proportion of NK cells, and low $\mathrm{CD} 4{ }^{+} \mathrm{CD} 25^{+} \mathrm{CD} 127$ Tregs were observed in pretreated ITP patients compared to controls $(p<0.02$, Figures $1 D, 2 B$, and $2 C)$. A higher $C D 4 / C D 8$ ratio and lower levels of NK cells were observed in the newly diagnosed group compared to the relapsed group (both $p<0.05$, Figures $1 \mathrm{D}$ and $2 \mathrm{~B}$ ). More Tregs were observed in the remission group compared to the relapsed group and newly diagnosed patients ( $p=0.009$, Figure $2 \mathrm{C}$ ). No difference in CD4/CD8 ratio or NK cells was observed between the relapsed and remission groups (both $p>0.05$, Figures $1 D$ and $2 B$ ).

\section{CCR7 in Primary Immune Thrombocytopenia}

The $\mathrm{CD}^{+}{ }^{+} \mathrm{CCR}^{+}$subset, $\mathrm{CD}^{+}{ }^{+} \mathrm{CCR} 7^{+}$subset, and $\mathrm{CCR} 7^{+}$subset of B cells and NK cells showed higher increases in the newly diagnosed group and the relapsed group compared to the

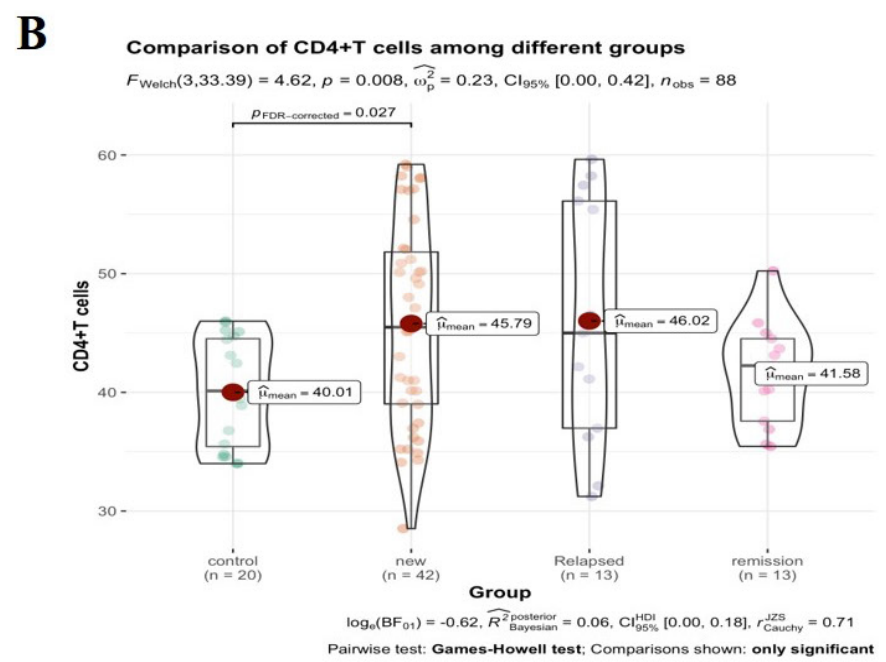

D

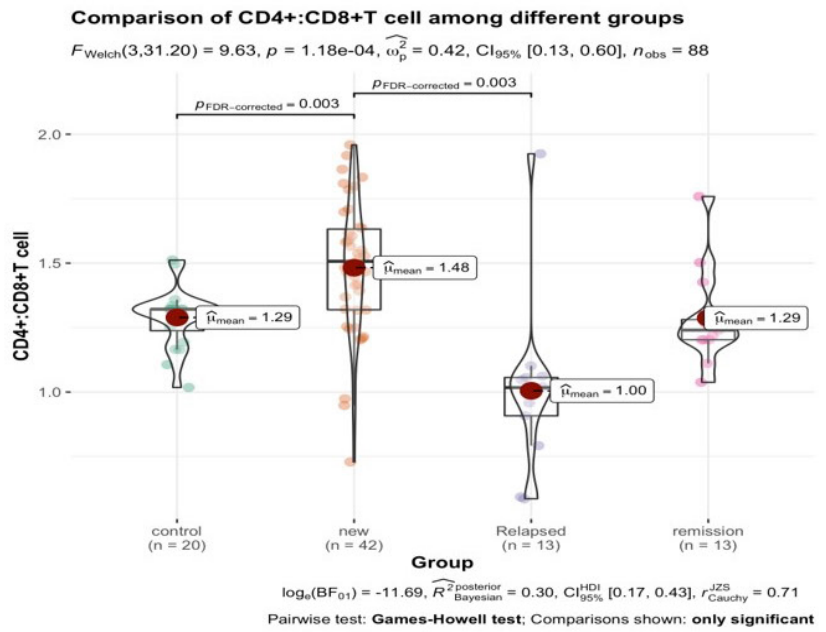

Figure 1. CD3 ${ }^{+}$T-cells, CD4 ${ }^{+}$T-cells, CD8 ${ }^{+}$T-cells, and $\mathrm{CD}^{+} / \mathrm{CD} 8^{+} \mathrm{T}$-cell ratio in the control, newly diagnosed, relapsed, and remission groups after treatment. (A) Mean values of CD3+ T-cells in the control, newly diagnosed, relapsed, and remission groups were 77.39, 74.06, 78.30, and 76.89, respectively. (B) Mean values of $C D 4^{+}$T-cells in the control, newly diagnosed, relapsed, and remission groups were 40.01, 45.79, 46.02, and 41.58, respectively. (C) Mean values of CD8+ T-cells in the control, newly diagnosed, relapsed, and remission groups were $32.46,31.43,47.39$, and 32.53 , respectively. (D) The CD4+CD8+ T-cell ratios in the control, newly diagnosed, relapsed, and remission groups were $12.9,1.48,1.00$, and 1.29 , respectively. 
controls and the remission group ( $p<0.05$, Figures $3 A-3 D)$, but there was no difference between the newly diagnosed group and the relapsed group in the $C \mathrm{CR} 7^{+}$subset of $\mathrm{B}$ cells and NK cells ( $p>0.05$, Figures $3 C$ and $3 D$ ). The levels of the $C D 4^{+} C C R 7^{+}$ subset and $\mathrm{CD}^{+}{ }^{+} \mathrm{CR} 7^{+}$subset in the relapsed group were slightly higher than those in the newly diagnosed group (both $\mathrm{p}<0.05$, Figures $3 \mathrm{~A}$ and $3 \mathrm{~B}$ ). The levels of $\mathrm{CCR}^{+}$subsets of CD4 ${ }^{+} \mathrm{T}$-cells, CD8 ${ }^{+} \mathrm{T}$-cells, NK cells, and B cells were lower in the remission group compared to the relapsed group ( $p<0.001$, Figures 3A-3D). Higher levels of the $\mathrm{CD} 8^{+} \mathrm{CCR} 7^{+}$subset and lower levels of NK cells were found in the remission group compared to the controls $(p<0.05$, Figures $3 B$ and $3 D)$. No difference in the $\mathrm{CD}^{+}{ }^{+} \mathrm{CCR} 7^{+}$subset or $\mathrm{CCR} 7^{+}$subset of $\mathrm{B}$ cells was found between the controls and the remission group $(p<0.001$, Figures $3 \mathrm{~A}$ and $3 \mathrm{C}$ ).

The ratio between the $\mathrm{CD} 4^{+} \mathrm{CCR} 7^{+}$subset and $\mathrm{CD} 8^{+} \mathrm{CCR} 7^{+}$ subset was lower in the ITP patients than the controls $(p<0.001$,

A

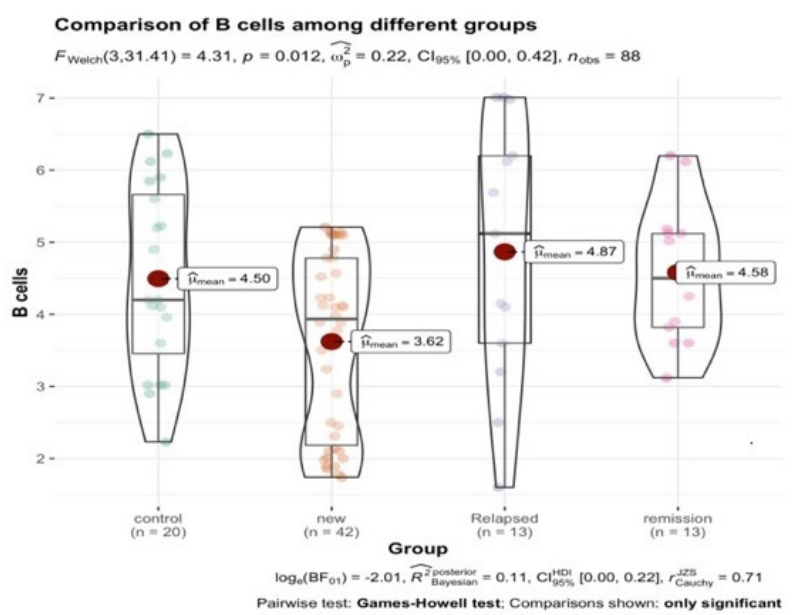

C
Figure 4A), but no differences were found among the newly diagnosed group, the relapsed group, and the remission group $(p>0.05$, Figure $4 A)$. There was a negative correlation between the $C D 8^{+} C C R 7^{+}$subset and platelet count for all groupings of ITP patients (both $p<0.001$, Figure 4B).

\section{Discussion}

ITP is an autoimmune disease, and although various mechanisms involved in ITP, including cytokines [11,12,13], immune cells $[14,15,16,17,18,19,20]$, T-cell receptor excision circles [21], and microRNAs [22], have been investigated, the pathogenesis of ITP still needs further study. Currently, drug treatments include steroid therapy in combination with other immunosuppressive drugs and thrombopoietin receptor agonists (e.g., thrombopoietin, eltrombopag, and romiplostim), which have shown not only limited efficacy [23] but also high toxicity or high cost. Thus, a more thorough understanding
B

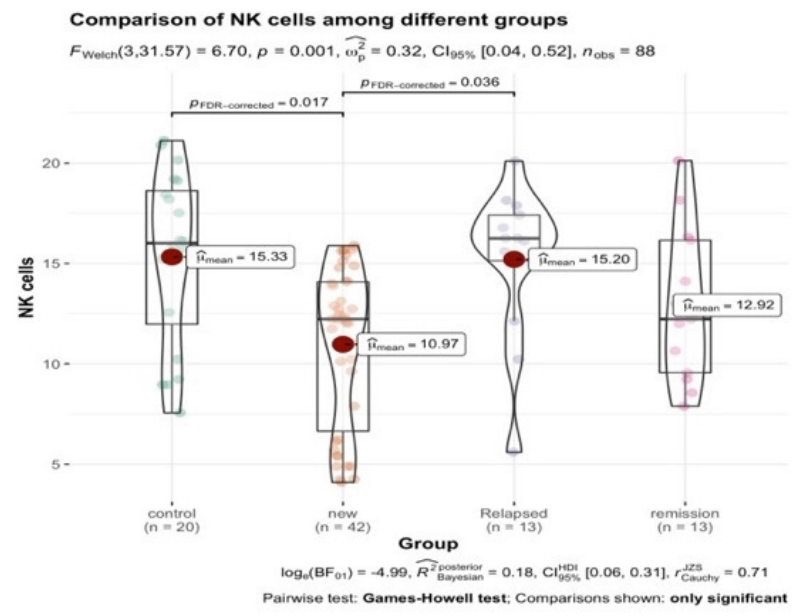

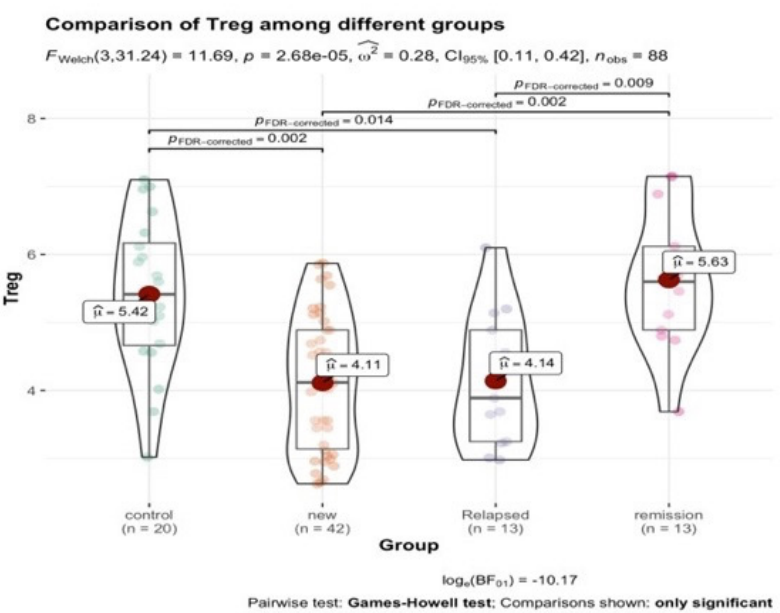

Figure 2. B cells, NK cells, and CD4+ Treg cells in the control, newly diagnosed, relapsed, and remission groups after treatment. (A) Mean values of B cells in the control, newly diagnosed, relapsed, and remission groups were 4.50, 3.62, 4.87, and 4.58, respectively. (B) Mean values of NK cells in the control, newly diagnosed, relapsed, and remission groups were 15.33, 10.97, 15.20, and 12.92, respectively. (C) Mean values of CD4+ regulatory T-cells (Tregs) in the control, newly diagnosed, relapsed, and remission groups were 5.42, $4.11,4.14$, and 5.63, respectively. 
of the immunopathogenesis of ITP is needed. Despite studies showing that increased levels of autoantibodies against self-antigens play a crucial role in platelet destruction, antiplatelet autoantibodies are detectable in only half of all ITP patients and other mechanisms are likely to be involved [20]. The pathophysiology of ITP remains complicated and requires further study. In this retrospective study, we analyzed PBMCs, including T-lymphocyte subsets, B lymphocytes, and NK cells, as well as the expression of CCR7 in 42 patients diagnosed with primary ITP before and after treatment in our department. We analyzed immune statuses and the relationship between the expression of CCR7 on lymphocyte subsets and therapeutic outcomes. Changes in CCR7 expression before and after treatment may be helpful for clinicians in selecting alternative treatments for ITP patients.

Abnormal T lymphocyte subpopulations in patients with ITP have been previously reported. CCR7 expression, which plays a critical role in T-cell maturation, differentiation, and function, has been reported on T-cells [24] and CCR7 ${ }^{+}$central memory T-cells

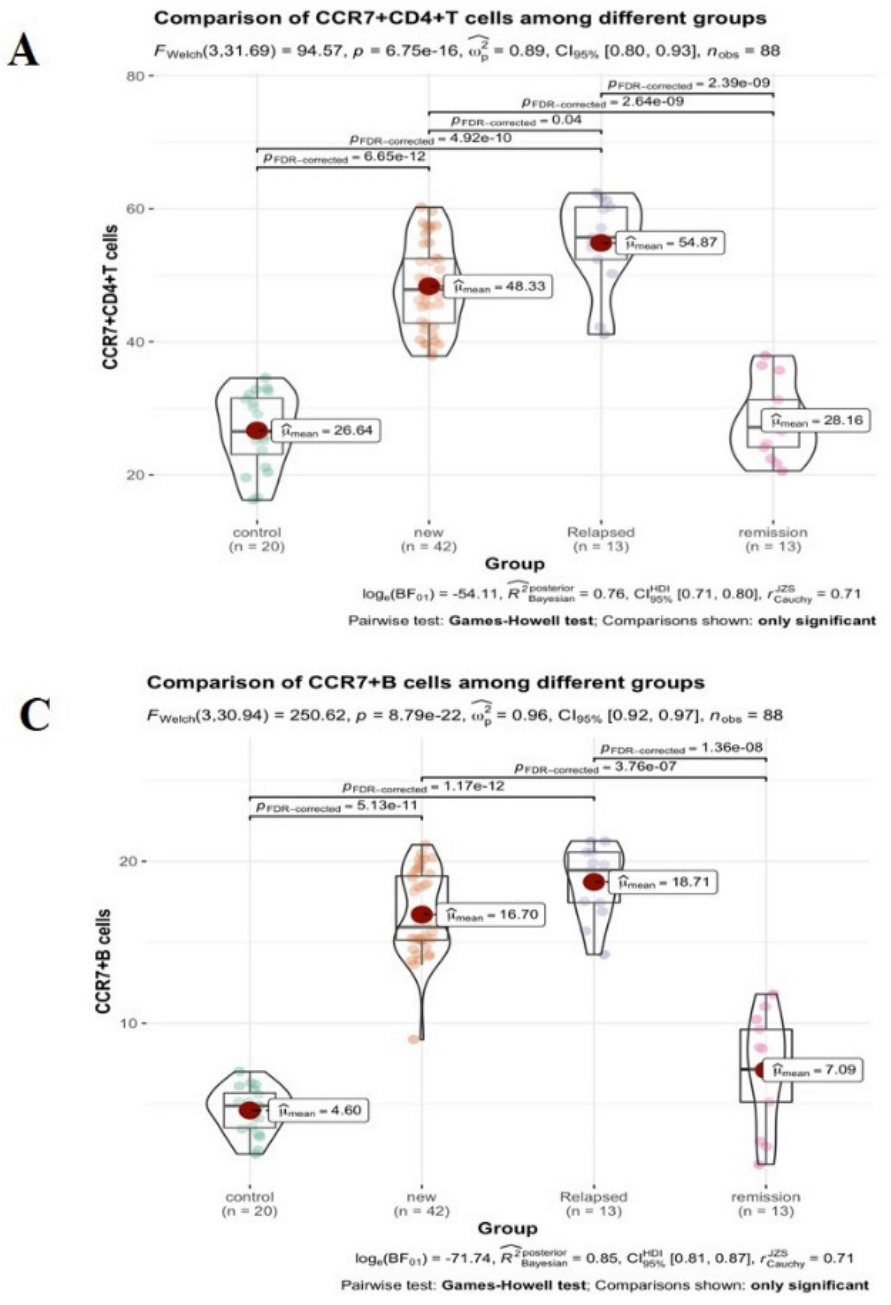

were associated with disease severity and immunoglobulin $\mathrm{E}$ in bronchial asthma. However, the function of CCR7 has not been elucidated in ITP.

Recent research has shown that the relative numbers of $\mathrm{CD}^{+}$ and $\mathrm{CD}^{+} \mathrm{T}$-cells are normal in ITP and that $\mathrm{CD} 8^{+} \mathrm{T}$-cells increase potential cytotoxicity in ITP [19]. However, other reports have indicated increased $C D 8^{+} T$ lymphocytes and decreased CD4/CD8 ratios in acute and chronic patients [25].

The present study found that CD4 $4^{+}$T-cells were increased in newly diagnosed patients and that $\mathrm{CD} 8^{+} \mathrm{T}$-cells were increased in relapsed patients. CD4/CD8 ratios were increased in newly diagnosed patients and decreased in relapsed patients. There were no significant differences between the patients with $C R$ and the controls. The differences in CD4/CD8 ratios may be related to the complex pathogenesis of ITP. According to treatment responses, the CD4/CD8 ratios almost returned to normal in the CR group even though there was no significant difference due to the small sample size. We also found that the CCR7 ${ }^{+}$
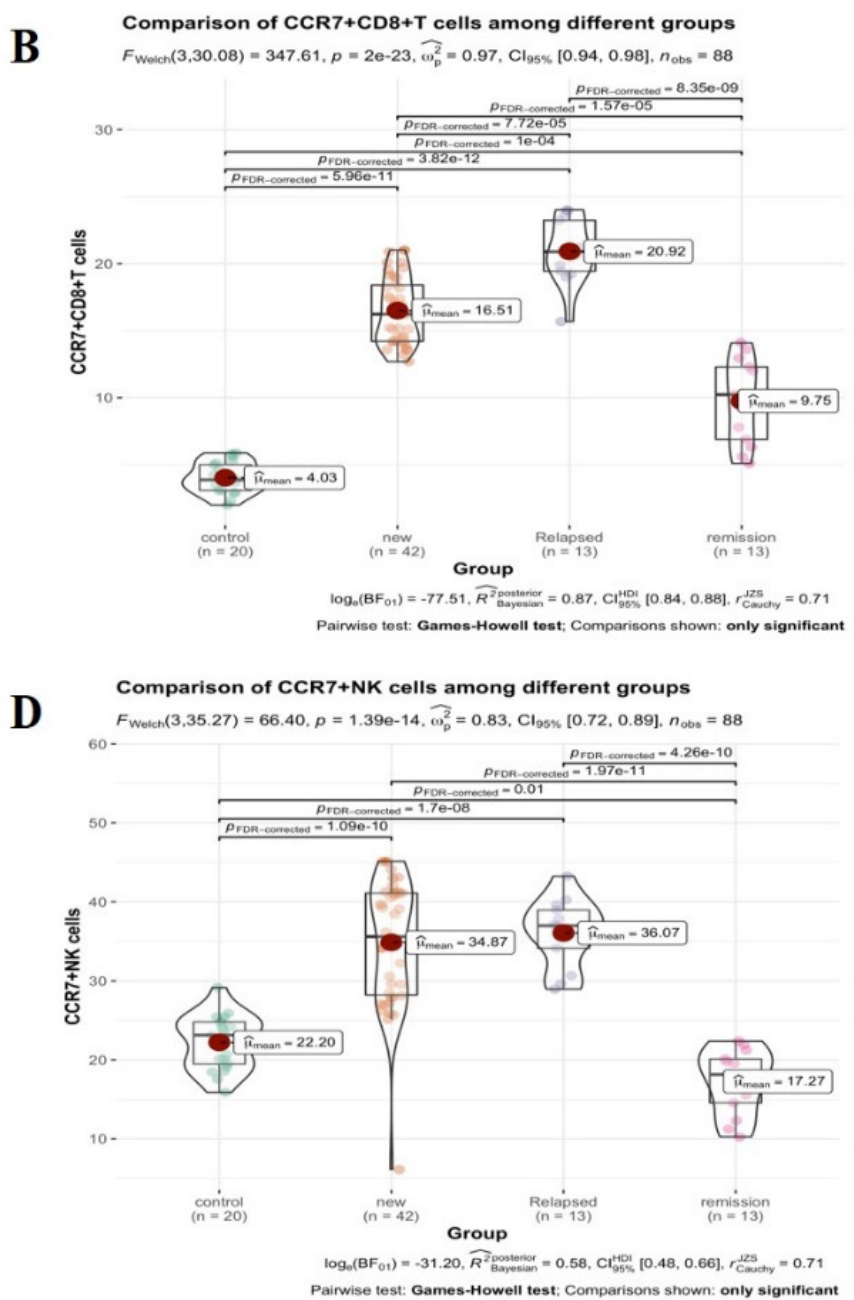

Figure 3. Expression of CCR7 on CD4+ T-cells (A), CD8 ${ }^{+}$T-cells (B), B cells (C), and NK cells (D) in the control, newly diagnosed, relapsed, and remission groups after treatment. 
subset of circulating CD4+ T-cells was significantly increased when patients were newly diagnosed before treatment. After treatment, the $\mathrm{CCR}^{+}$subset of circulating $\mathrm{CD} 4^{+}$T-cells was significantly decreased in the CR group, and this subset was significantly increased in the relapsed group. The change in the $\mathrm{CCR7}^{+}$subset of circulating $\mathrm{CD} 4^{+} \mathrm{T}$-cells may be an indicator of effective treatment. However, it is not clear whether change in the proportion of $\mathrm{CCR} 7^{+} \mathrm{CD} 4^{+}$T-cells was caused by effective treatment or whether change in the proportion of $\mathrm{CCR7} 7^{+} \mathrm{CD} 4^{+}$ T-cells led to effective treatment. Psarras et al. [26] reported that CCR7 promotes human plasmacytoid dendritic cell maturation by upregulating chemokine receptors, thereby inducing $\mathrm{CD} 4^{+}$ T-cell proliferation and activation. CCR7 expression on CD4 ${ }^{+}$ T-cells in two cases of Blau syndrome, an inflammatory disorder characterized by uveitis, was reported to be increased [5]. CCR7 promotes T helper 17 (Th17)-mediated autoimmune disease [27], and the increased differentiation of Th17 cells is a vital promoter of ITP progression [28]. Whether the increased expression of CCR7 on CD4+ T-cells also promotes the differentiation of Th17 cells in ITP remains to be further studied. Moschovakis et al. [6] reported that a lack of CCR7 signaling favors the development of Th2 cells in immunodeficient mice, suggesting that CCR7 signaling affects the Th1/Th2 polarization potential of $\mathrm{CD}^{+}$ T-cells. Some studies $[29,30]$ have shown that increased Th17 cells are consistent with Th1 polarization in ITP. It remains unknown whether CCR7 signals affect Th1/Th2 polarization through Th17 cells to participate in the occurrence and development of ITP. Gupta et al. [31] reported that $\mathrm{CD}^{+}{ }^{+} \mathrm{CCR}^{+}{ }^{+} \mathrm{CD} 45 \mathrm{RA}^{-}$Tregs inhibited $\mathrm{B}$ cell proliferation and immunoglobulin production in healthy PB. In the present study, the $\mathrm{CCR7}^{+}$subset of circulating CD8 ${ }^{+} \mathrm{T}$-cells was significantly increased when patients were newly diagnosed before treatment, and this subset was significantly decreased in the CR group but significantly increased in the relapsed group after treatment. We



did not further classify CCR7 ${ }^{+} \mathrm{CD} 8^{+} \mathrm{T}$-cells, but we found that the proportion of $\mathrm{CCR}^{+} \mathrm{CD} 8^{+} \mathrm{T}$-cells was inversely correlated with platelet count in ITP patients. Kim et al. [32] reported that CCR7 expression on circulating $\mathrm{CD}^{+} \mathrm{T}$ lymphocytes protects those T lymphocytes from apoptosis in squamous cell carcinoma of the head and neck. However, the presence of this phenomenon in ITP needs to be further explored.

B cells play a key role in the pathogenesis of ITP by producing platelet autoantibodies. Many studies have shown that patients with ITP may have more B cells in PB than healthy individuals [33]. In the present study, there was no significant difference in the number of B cells of newly diagnosed and relapsed patients compared to the controls and the CR group. Compared to healthy controls, Li et al. [34] reported that the proportions of $\mathrm{CD}_{19}{ }^{+} \mathrm{B}$ cells in ITP patients without treatment were comparable. In the present study, we did not analyze the B-cell subsets and antiplatelet antibody (IgG, IgA, and IgM) levels, but further research on these aspects will be conducted. The CCR7 ${ }^{+}$ subset of circulating CD19+ $B$ cells was significantly increased when patients were newly diagnosed before treatment. After treatment, the $\mathrm{CCR7}^{+}$subset of circulating $\mathrm{CD}^{+} 9^{+} \mathrm{B}$ cells was significantly decreased in the CR group but significantly increased in the relapsed group. CCR7 regulates the trafficking and retention of B cells. Moschovakis et al. [6] reported that CCR7 signaling is involved in B-cell activation in vivo. It remains to be further explored whether CCR7 also participates in the activation and proliferation of $B$ cells in ITP patients.

Several studies on NK cells have been conducted in ITP, but the results are contradictory. The present study found that NK cells were significantly decreased in newly diagnosed patients compared to controls but significantly increased in the relapsed group compared to newly diagnosed patients. However, no significant difference was found between ITP patients who were

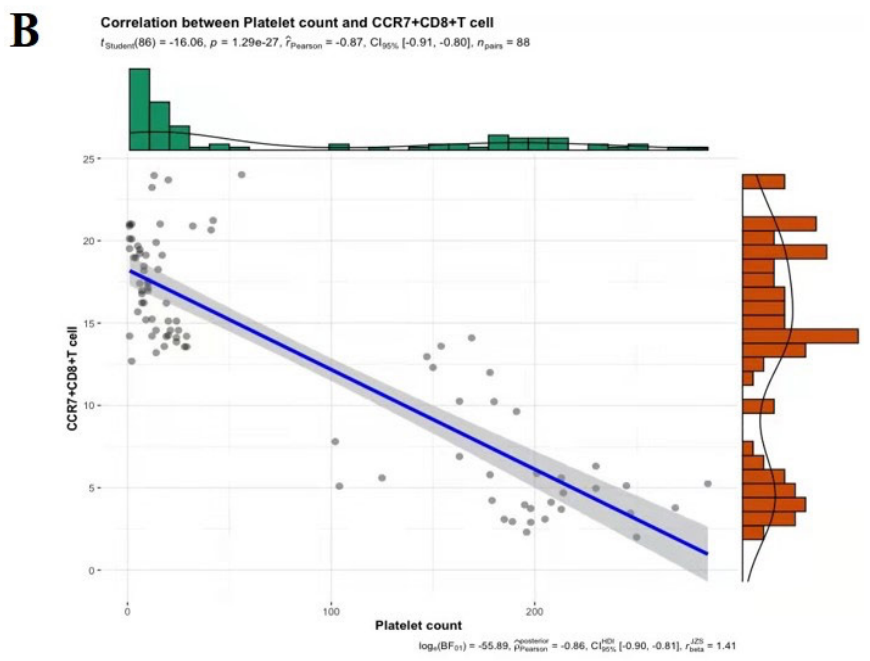

Figure 4. (A) The $C D 4^{+} C C R 7^{+} T$-cell/ $C D 8^{+} C C R 7^{+} T$-cell ratio in the control, newly diagnosed, relapsed, and remission groups after treatment. (B) Correlation between platelet count and CCR7 ${ }^{+} \mathrm{CD} 8^{+} \mathrm{T}$-cells. 
effectively treated or not treated in the present study, which may be due to the small sample size, and we will perform more studies in the future. In contrast to $\mathrm{CD}^{+} \mathrm{T}$-cells, NK cells were not involved in thrombocytopenia [35]. Our study also showed that NK cells were not involved in thrombocytopenia. The CCR7 ${ }^{+}$ subset of NK cells was significantly increased when patients were newly diagnosed before treatment. After treatment, the $\mathrm{CCR7}^{+}$subset of NK cells was significantly decreased in the CR group but significantly increased in the relapsed group. The $\mathrm{CCR7}^{+}$subset of NK cells was similar to the $\mathrm{CCR} 7^{+} \mathrm{CD} 8^{+} \mathrm{T}$-cell subset and $\mathrm{CCR} 7^{+} \mathrm{CD} 19^{+}$B-cell subset. Further research is needed to explore this correlation. Even if the ITP patients were in CR after treatment, the expression of CCR7 did not return to a normal level, which may account for the existing immune function deficiency in ITP patients who do not recover or for recurrence in some patients with ITP. Moreover, the expression of CCR7 was the highest in the relapsed group. It remains to be further explored whether CCR7 is also involved in disease recurrence or outcome after recurrence.

Tregs are a T-cell subset with immunomodulatory properties that can inhibit effector cells, such as CD4 ${ }^{+} \mathrm{T}$-cells, CD8 ${ }^{+} \mathrm{T}$-cells, and B-cells, and induce tolerance to dendritic cells [36]. Many studies have reported a low frequency of circulating Tregs in ITP patients. Our study has similarly shown that Tregs were reduced in newly diagnosed and relapsed patients, and these patients recovered following treatment in the CR group, suggesting that an approach involving the restoration of Tregs may be another treatment route in ITP.

\section{Conclusion}

ITP is a heterogeneous disease and a syndrome in which multiple pathways leading to thrombocytopenia are involved. Identification of common key molecules among different pathways may aid in identifying an effective therapeutic strategy. CCR7 may be such a molecule, and its specific mechanism in ITP still needs further exploration. Because our sample size was small and the test results were not comprehensive, we plan to expand the sample size and further explore the specific mechanism of CCR7 in the pathogenesis of ITP in future studies.

\section{Ethics}

Ethics Committee Approval: Ethics clearance was granted from Institutional Review Board of Shaoxing People's Hospital for the present study.

\section{Authorship Contributions}

Concept: D.L.; Design: D.L.; Data Collection or Processing: G-Z.Z.; Analysis or Interpretation: L.Z.; Literature Search: W-Y.F.; Writing: D.L.
Conflict of Interest: No conflict of interest was declared by the authors.

Financial Disclosure: The authors declared that this study received no financial support.

\section{Acknowledgments}

This work was supported by the Shaoxing Public Welfare Technology Application Research Program (Grant Nos. 2018C30066 and 2020A13008).

\section{References}

1. Schifferli A, Nimmerjahn F, Kühne T. Immunomodulation in primary immune thrombocytopenia: a possible role of the Fc fragment of romiplostim? Front Immunol 2019;10:1196.

2. Tinazzi E, Osti N, Beri R, Argentino G, Veneri D, Dima F, Bason C, Jadav G Dolcino M, Puccetti A, Lunardi C. Pathogenesis of immune thrombocytopenia in common variable immunodeficiency. Autoimmun Rev 2020;19:102616.

3. Dzopalić T, Božić-Nedeljković B, Jurišić V. Function of innate lymphoid cells in the immune-related disorders. Hum Cell 2019;32:231-239.

4. Jiang BC, Liu T, Gao YJ. Chemokines in chronic pain: cellular and molecular mechanisms and therapeutic potential. Pharmacol Ther 2020;212:107581.

5. Napier RJ, Lee EJ, Davey MP, Vance EE, Furtado JM, Snow PE, Samson KA, Lashley SJ, Brown BR, Horai R, Mattapallil MJ, Xu B, Callegan MC, Uebelhoer LS, Lancioni CL, Vehe RK, Binstadt BA, Smith JR, Caspi RR, Rosenzweig HL. T-cell-intrinsic role for Nod2 in protection against Th17-mediated uveitis. Nat Commun 2020;11:5406.

6. Moschovakis GL, Bubke A, Dittrich-Breiholz O, Braun A, Prinz I, Kremmer E, Förster R. Deficient CCR7 signaling promotes TH2 polarization and B-cell activation in vivo. Eur J Immunol 2012;42:48-57.

7. Rodriguez-Fernandez $\mathrm{JL}$, Criado-Garcia 0 . The chemokine receptor CCR7 uses distinct signaling modules with biased functionality to regulate dendritic cells. Front Immunol 2020;11:528.

8. Kodati S, Chauhan SK, Chen Y, Dohlman TH, Karimian P, Saban D, Dana R. CCR7 is critical for the induction and maintenance of Th17 immunity in dry eye disease. Invest Ophthalmol Vis Sci 2014;55:5871-5877.

9. Belikan P, Bühler U, Wolf C, Pramanik GK, Gollan R, Zipp F, Siffrin V. CCR7 on $\mathrm{CD}^{+}{ }^{+} \mathrm{T}$-cells plays a crucial role in the induction of experimental autoimmune encephalomyelitis. J Immunol 2018;200:2554-2562.

10. Moschovakis GL, Bubke A, Friedrichsen M, Ristenpart J, Back JW, Falk CS, Kremmer E, Förster R. The chemokine receptor CCR7 is a promising target for rheumatoid arthritis therapy. Cell Mol Immunol 2019;16:791-799.

11. Haznedaroglu IC, Büyükaşik Y, Koşar A, Kirazh S, Dündar SV. Thrombopoietin, interleukin-6, and $\mathrm{P}$-selectin at diagnosis and during post-steroid recovery period of patients with autoimmune thrombocytopenic purpura. Ann Hematol 1998;77:165-170.

12. Saitoh T, Tsukamoto $N$, Koiso $H$, Mitsui $T$, Yokohama $A$, Handa H, Karasawa M, Ogawara H, Nojima Y, Murakami H. Interleukin-17F gene polymorphism in patients with chronic immune thrombocytopenia. Eur J Haematol $2011 ; 87: 253-258$.

13. Li J, Sullivan JA, Ni H. Pathophysiology of immune thrombocytopenia. Curr Opin Hematol 2018;25:373-381.

14. Swinkels $M$, Rijkers $M$, Voorberg J, Vidarsson $G$, Leebeek FWG, Jansen AJG. Emerging concepts in immune thrombocytopenia. Front Immunol 2018;9:880.

15. Cooper N, Ghanima W. Immune thrombocytopenia. N Engl J Med 2019;381:945-955. 
16. Han $P, Y u T$, Hou $Y$, Zhao $Y$, Liu $Y$, Sun $Y$, Wang $H, X u$, Li G, Sun $T, H u X$, Liu $X$, Li L, Peng J, Zhou H, Hou M. Low-dose decitabine inhibits cytotoxic $T$ lymphocytes-mediated platelet destruction via modulating PD-1 methylation in immune thrombocytopenia. Front Immunol 2021;12:630693.

17. Williams EL, Stimpson ML, Lait PJP, Schewitz-Bowers LP, Jones LV, Dhanda $A D$, Lee RWJ, Bradbury CA. Glucocorticoid treatment in patients with newly diagnosed immune thrombocytopenia switches $\mathrm{CD} 14^{++} \mathrm{CD} 16^{+}$intermediate monocytes from a pro-inflammatory to an anti-inflammatory phenotype. Br J Haematol 2021;192:375-384.

18. Zhang $X$, Wang $Y$, Zhang D, Li H, Zhou Z, Yang R. CD70-silenced dendritic cells induce immune tolerance in immune thrombocytopenia patients. $\mathrm{Br} \mathrm{J}$ Haematol 2020;191:466-475.

19. Vrbensky JR, Arnold DM, Kelton JG, Smith JW, Jaffer AM, Larché M, Clare $R$, Ivetic $N$, Nazy I. Increased cytotoxic potential of $C D 8^{+}$T-cells in immune thrombocytopenia. Br J Haematol 2020;188:e72-e76.

20. Audia S, Mahévas M, Samson M, Godeau B, Bonnotte B. Pathogenesis of immune thrombocytopenia. Autoimmun Rev 2017;16:620-632.

21. Santana-Santos D, Liphaus BL, Beatrice JM, Carneiro JDA, CarneiroSampaio MMS, Rangel-Santos A. Low T-cell receptor excision circles (TREC) in children and adolescents with immune thrombocytopenia. Br J Haematol 2021;192:e99-e102.

22. Wang $Y$, Zhang J, Su $Y$, Wang $C$, Zhang G, Liu X, Chen $Q$, Lv M, Chang $Y$, Peng J, Hou M, Huang $X$, Zhang $X$. miRNA-98-5p targeting IGF2BP1 induces mesenchymal stem cell apoptosis by modulating PI3K/Akt and p53 in immune thrombocytopenia. Mol Ther Nucleic Acids 2020;20:764-776.

23. Moulis G, Lapeyre-Mestre M, Montastruc JL, Sailler L. Exposure to noncorticosteroid treatments in adult primary immune thrombocytopenia before the chronic phase in the era of thrombopoietin receptor agonists in France. A nationwide population-based study. Autoimmun Rev 2015;14:168-173.

24. Yashiro T, Takeuchi H, Kasakura K, Nishiyama C. PU.1 regulates Ccr7 gene expression by binding to its promoter in naïve $\mathrm{CD}^{+} \mathrm{T}$-cells. FEBS Open Bio 2020;10:1115-1121.

25. El-Rashedi FH, El-Hawy MA, Helwa MA, Abd-Allah SS. Study of $\mathrm{CD}^{+}$, $\mathrm{CD}^{+}$, and natural killer cells $\left(\mathrm{CD} 16^{+}, \mathrm{CD}^{+} 6^{+}\right)$in children with immune thrombocytopenic purpura. Hematol Oncol Stem Cell Ther 2017;10:8-14.
26. Psarras A, Antanaviciute A, Alase A, Carr I, Wittmann M, Emery P, Tsokos $\mathrm{GC}$, Vital EM. TNF- $\alpha$ regulates human plasmacytoid dendritic cells by suppressing IFN- $\alpha$ production and enhancing T-cell activation. J Immunol 2021;206:785-796.

27. Ma T, Luan S, Tao R, Lu D, Guo L, Liu J, Shu J, Zhou X, Han Y, Jia Y, Li G, Zhang $H$, Han W, Han Y, Li H. Targeted migration of human adipose-derived stem cells to secondary lymphoid organs enhances their immunomodulatory effect and prolongs the survival of allografted vascularized composites. Stem Cells 2019;37:1581-1594.

28. Li J, Xia $Y$, Fan $X, W u X$, Yang $F$, Hu S, Wang Z. Extracellular vesicles derived from miR-199a-5p-modified adipose-derived mesenchymal stem cells alleviate immune thrombocytopenia by inhibiting $\mathrm{T}$ helper 17 differentiation. Lab Invest 2021;101:318-327.

29. Zhu X, Ma D, Zhang J, Peng J, Qu X, Ji C, Hou M. Elevated interleukin-21 correlated to Th17 and Th1 cells in patients with immune thrombocytopenia. J Clin Immunol 2010;30:253-259.

30. Zhang J, Ma D, Zhu X, Qu X, Ji C, Hou M. Elevated profile of Th17, Th1 and Tc1 cells in patients with immune thrombocytopenic purpura. Haematologica 2009;94:1326-1329.

31. Gupta S, Su H, Agrawal S. CD8 Treg cells inhibit B-cell proliferation and immunoglobulin production. Int Arch Allergy Immunol 2020;181:947-955.

32. Kim JW, Ferris RL, Whiteside TL. Chemokine C receptor 7 expression and protection of circulating $\mathrm{CD}^{+} \mathrm{T}$ lymphocytes from apoptosis. Clin Cancer Res 2005;11:7901-7910.

33. Culić S, Labar B, Marusić A, Salamunić I. Correlations among age, cytokines, lymphocyte subtypes, and platelet counts in autoimmune thrombocytopenic purpura. Pediatr Blood Cancer 2006;47(5 Suppl):671-674.

34. Li X, Zhong H, Bao W, Boulad N, Evangelista J, Haider MA, Bussel J, Yazdanbakhsh K. Defective regulatory B-cell compartment in patients with immune thrombocytopenia. Blood 2012;120:3318-3325.

35. Olsson $B$, Andersson PO, Jernås $M$, Jacobsson $S$, Carlsson $B$, Carlsson LM, Wadenvik H. T-cell-mediated cytotoxicity toward platelets in chronic idiopathic thrombocytopenic purpura. Nat Med 2003;9:1123-1124.

36. Ohue Y, Nishikawa H. Regulatory T (Treg) cells in cancer: can Treg cells be a new therapeutic target? Cancer Sci 2019;110:2080-2089. 